\title{
A Review of Probiotics Supplementation in Healthy Adults: Helpful or Hype?
}

Saman Khalesi ${ }^{1}$, Nick Bellissimo ${ }^{2}$, Corneel Vandelanotte ${ }^{1}$, Susan Williams ${ }^{1}$, Dragana Stanley ${ }^{3}$, Christopher Irwin ${ }^{4}$

${ }^{1}$ Physical Activity Research Group, Appleton Institute, School of Health Medical and Applied Sciences, Central Queensland University, Rockhampton, Australia

${ }^{2}$ School of Nutrition, Ryerson University, Toronto, Canada

${ }^{3}$ School of Medical and Applied Sciences, Central Queensland University, Rockhampton, Australia

${ }^{4}$ Menzies Health Institute Queensland and School of Allied Health Sciences, Griffith University, Gold Coast, Australia

Running title: Probiotics for Healthy Adults

\section{Correspondence:}

Saman Khalesi (MSc, PhD), School of Health, Medical and Applied Sciences, Central Queensland University, Rockhampton, 4701 QLD, Australia. Phone:

+610749306970, email: s.khalesi@cqu.edu.au; saman.khalesi@gmail.com

Authors declare no source of funding for this work. 


\begin{abstract}
Probiotic supplements have a positive impact on several health outcomes. However, the majority of published studies have focused on populations with specific health pathologies. Therefore, this study reviewed the current literature on the health effects of probiotics consumption in 'healthy adults'. The findings from this review may help guide consumers, researchers and manufacturers regarding probiotics supplementation. Relevant literature published between 1990 and August 2017 was reviewed. Studies were included if they were experimental trials, included healthy adults, used live bacteria and had accessible full-text articles published in English. Included studies were classified according to common foci that emerged. Forty-five studies were included in this review. Five foci emerged: gut microbiota changes $(n=15)$; immune system response $(n=16)$; lipid profile and cardiovascular disease risk $(n=14)$; gastrointestinal discomfort $(n=11)$; health of female reproductive health $(n=4)$. Results suggest that probiotics supplementation in healthy adults can lead to transient improvement in gut microbiota concentration of supplement-specific bacteria. Evidence also supports the role of probiotics in improving immune system responses, stool consistency, bowel movement, and vaginal lactobacilli concentration. There is insufficient evidence to support the role of probiotics to improve blood lipid profile. Probiotics consumption can improve in the immune, gastrointestinal and female reproductive health systems in healthy adults. However, this review failed to support the ability of probiotics to cause persistent changes in gut microbiota, or improve lipid profile in healthy adults. The feasibility of probiotics consumption to provide benefits in healthy adults requires further investigation.
\end{abstract}

Keywords: probiotics; health; supplement; review; gut microbiota; immune system response; lipid profile; cardiovascular disease; gastrointestinal discomfort; female reproductive health. 


\section{Introduction}

The use of fermented products can be traced back to ancient Egyptian and Middle-Eastern civilizations, when fermentation was a method of food preservation (1). However, it was not until the early 1900's that associations between human longevity and yoghurt consumption (containing lactobacilli strains of bacteria used for fermentation) were observed $(2,3)$. It was also around this time when belief originated that fermented products could alter the microflora of the large intestine and reduce toxin production in the intestine $(2,3)$. In the early 1900s Bifidobacterium was first isolated and was hypothesized to have anti-pathogenic effects (1). The next major advancement was in the 1960's, when the term 'probiotic' was first coined for bacterial species deemed to be beneficial to the gastrointestinal (GI) tract. However, it was not until 2001 that the World Health Organization formally defined probiotics as "live microorganisms, which, when administered in adequate amounts, confer a health benefit on the host" (4).

The ability of probiotics to impart health benefits has prompted increased scientific interest for several decades. Evidence from animal and human studies has demonstrated potentially favourable benefits of probiotics, including modulating the number and diversity of beneficial gut microbiota $(5,6)$; reducing symptoms associated with various GI disorders $(7,8)$; improving blood cholesterol levels and blood lipid profile $(9,10)$; removal of mycotoxins (11); reducing blood pressure and hypertension (12); improving blood glucose tolerance and diabetes control $(13,14)$; and enhancing mental state and cognitive function (15).

The translation of these health benefits in the public forum has led to increased demand for probiotic products/supplements over the last decade. This has prompted a rapid increase in the development of new probiotic containing foods and supplements for the consumer market (16). While research has demonstrated positive effects of probiotic consumption on several health outcomes, the majority of the published literature is in populations with underlying pathologies. Evidence supporting the health-promoting effects of probiotics in healthy adults is limited and less consistent $(17,18)$. Despite this, probiotic manufacturers promote the use of their product to a broader consumer market than those with specific health conditions. Whether probiotics supplementation conveys benefit in healthy individuals is questionable. Therefore, this study aimed to review the literature on the health effects of probiotics consumption in 'healthy adults'. The results of this review may guide the decision-making of consumers, researchers and manufacturers regarding probiotics supplementation. 


\section{Methods}

\section{Literature search}

Due to the number of outcomes included and the wide variety of studies varying in study design, experimental setting and dependent measures (e.g. immune response to different viruses or a different population of older and younger adults), a systematic review was not performed. However, a systematic approach was employed to search and review the relevant literature. The online databases PubMed (MEDLINE), Cumulative Index to Nursing and Allied Health Literature (CINAHL), and Cochrane Library (Central) were searched from 1990 through to August 2017. The reference lists of included studies were also manually searched for relevant studies. Following a PICOS (Population, Intervention, Comparison, Outcome, Setting) approach, the online literature search used a combination of the following basic and MeSH (Medical Subject Headings) terms: 'healthy volunteers' or 'healthy adults' as the population, 'probiotics', 'lactobacillus' or 'bifidobacterium' as the intervention, 'placebo' or 'control' as the comparison, 'controlled trials' or 'non-controlled trials' as the study design. During the preparation and presentation of this review, the PRISMA guidelines were followed (19).

\section{Study eligibility and selection}

Studies were included if they: (1) were experimental trials, (2) included adults, aged 18 years and older, (3) used live bacteria (probiotics), (4) included healthy adults, and (4) had accessible full-text publications in English. Healthy adults were defined as individuals with no reported status of the chronic or acute diseases, including cardiovascular disease, obesity (Body Mass Index $\left.(\mathrm{BMI}) \geq 30 \mathrm{~kg} / \mathrm{m}^{2}\right)$, liver disease, diabetes, chronic GI problems, autoimmune disease, cancer, psychological disorder, etc. Adults who reported having symptoms consistent with the common cold, who were overweight (BMI $25-29.9 \mathrm{~kg} / \mathrm{m}^{2}$ ) or smokers, were not excluded. Studies were excluded if probiotics treatment was mixed with other ingredients, or if pregnant women or both healthy and unhealthy adults were included as participants in one group.

The searched literature was initially screened by reviewing titles and abstracts. The full text of all relevant records was then reviewed. Two researchers were involved in the screening process and review of the literature. Eligible articles were only included when agreement was reached between the two researchers. In the case of any disagreement, a third reviewer was involved. 


\section{Data collection and synthesis}

Eligible literature was classified based on the most prominent themes that emerged from the literature search. Studies with similar outcomes were grouped if more than three trials were classified in the relevant group [Gut microbiota changes, Immune system response, Lipid profile and cardiovascular disease risk, GI discomfort and Female reproductive health]. In each group, methodology characteristics and outcomes were extracted. A narrative synthesis was used to review the effect of probiotics consumption on outcomes in each classification. The Cochrane Handbook for Systematic Review of Interventions (20) was followed as a guideline to review literature.

\section{Results}

Forty-five studies were included in the overall review. A summary of the review process and study selection criteria is presented in Figure 1.

\section{Gut microbiota colonization}

The proposed health benefits of probiotics are often initially measured at the gut microbiota level (6). Changes in the concentration and composition of intestinal microorganisms would suggest that probiotics are effective, at least in terms of colonization (6). Fifteen studies from the literature search were included in this classification group. Findings from these studies are summarised in Table 1. Of the fifteen studies include, fourteen suggested that probiotics supplementation is likely to increase the fecal count of specific bacterial strains administered in healthy adults. However, changes in the total count, diversity and composition of gut microbiota were only reported in three studies $(6,21,22)$. It also appears that changes in the gut microbiota of healthy adults following probiotic supplementation are temporary and return to pre-treatment levels within one to three weeks once supplementation has ceased (23, 24).

No obvious conclusions regarding the effects of dose, duration or strain of probiotics on changes in gut microbiota can be made based on the studies included in this review (Table 1). In order to transition through the GI tract and colonise the gut, probiotics need to be viable (i.e., contain adequate live bacteria) and resistant (i.e., survive) to stomach acidity and bile salts $(25,26)$. Some probiotic strains of the Bifidobacterium and Lactobacillus species such as B. animalis lactic (27), L. acidophilus johnsonii $(27,28)$ and L. casei Shirota (29) are 
reported as being resistant to low $\mathrm{pH}$ environments, thus appear to have good survival rates. In addition, $L$. acidophilus, $B$. longum and $B$. infantis have demonstrated good resistance to bile salts $(30,31)$. Encapsulation and microencapsulation manufacturing techniques have provided more efficient ways of delivering probiotics and preserving their viability (32). Although these methods may improve the survival of bacteria, they do not guarantee colonization of the probiotic bacteria in the intestine. The type of bacteria and the GI environment (33) also influence bacterial colonization. However, colonization may not necessarily be required for changes in the gut microbiota (31). The passage of probiotic bacteria (e.g. bifidobacteria) itself through the gut may be sufficient to reduce colonies of pathogenic bacteria by reducing their adhesion and competitive nature (34).

An ideal environment modulating the colonization of probiotics is one with adequate food to support the growth of healthy bacteria and reduce competition (25). The host's diet is an important determinant of gut microbiota biodiversity. Fermentable carbohydrate supports the growth and colonization of selective bacteria in the gut. The term 'prebiotics' (35) is used in reference to these fermentable fibers that resist gastric acidity and are able to stimulate the growth and activity of beneficial bacteria in the gut (36). Although commercially available (i.e., inulin, fructo-oligosaccharides, galacto-oligosaccharides), these fibers are abundant in natural foods such as fruit and vegetables (36). Evidence suggests that prebiotics consumption can improve the faecal count of beneficial bacteria (especially bifidobacteria) $(37,38)$ and maintain gut health.

When gut microbiota dysbiosis exists (e.g., diarrhea), prebiotics alone may not be able to return gut microbiota to its equilibrium. Despite skepticism about the influence of probiotics on the gut microbiota of healthy adults, probiotics have proven beneficial effects when dysbiosis exists $(7,39)$. Aging is also associated with a relative dysbiosis in gut microbiota. Reductions in bifidobacteria count, diversity and an increase in pathogenic bacteria are observed in the elderly $(40,41)$. Lahti et al. (23) reported that probiotic supplementation in healthy elderly adults could improve this age-related dysbiosis (Table 1). Overall, it seems that probiotic supplementation in healthy adults can lead to an increase in the colonization of specific probiotic strains. However, this increase may be transient and return to baseline after supplementation stops. Further studies need to focus on the sustainability of probiotics colonization in gut microbiota. 


\section{Immune system response}

Probiotics have been proposed to improve intestinal defense mechanisms against pathogenic microorganisms, enhance the immune system and reduce the likelihood of respiratory infections $(42,43)$. Sixteen studies from the literature search were included in this classification group, with findings summarized in Table 2. Eight studies reported the effect of probiotic consumption on common respiratory infections such as cold and flu. All of the three studies reporting on the effect on the common cold support a beneficial effect of probiotics supplementation at increasing immunity against the common cold in healthy adults (albeit in a limited number of studies) (Table 2). Reductions in the incidence $(44,45)$, duration $(44,46)$ and symptoms $(44,46)$ associated with common cold are commonly observed in healthy adults when a probiotics intervention is administered.

In contrast, the effect of probiotics supplementation on immune responses against influenza infection in healthy adults is less consistent $(43,47,48)$. In vitro exposure of T cells collected from 10 individuals (supplied with probiotics for 30 days) to the influenza A virus showed a significant increase in TNF- $\alpha$ (43). This suggests enhancement of T cell responses to a respiratory tract infection. These findings are supported in a larger study $(n=465$ participants supplemented with probiotics for 150 days), which indicated a significantly reduced risk of respiratory illness (49). However, these findings are in contrast with the results of several other studies indicating that probiotic supplementation had no influence on the incidence (47, $48,50)$ or severity $(47,48)$ of the flu.

The effect of probiotics on immune function of healthy adults are summarised in Table 2 . Ten studies reported improvement in the immune function by activating $\mathrm{T}$ lymphocytes, including cytotoxic plus and T helper cells (CD8+ and CD4+) after probiotics consumption (46, 51, $52)$, increase natural killer (NK) cell activity $(45,51,53,54)$, reduce the pro-inflammatory cytokines IL-12, IL-6 and IL-4 $(51,53,55)$ and increase anti-inflammatory cytokines IL-10 $(53,56)$. However, there is no consistent and clear relationship between the effects observed and the dose, duration and type of probiotic strains administered. Overall, it appears that probiotic supplementation in healthy adults can improve immune function and the immune response to common cold infections. However, the immune response to influenza infection and the effective duration, dose and type of probiotics supplementation require further investigation. 


\section{Lipid profile and cardiovascular disease risk}

Elevated low-density lipoprotein cholesterol (LDL-C) and triglycerides (TG), low levels of high-density lipoprotein cholesterol (HDL-C), increase in body mass index (BMI), blood glucose and pro-inflammatory markers are major risk factors of cardiovascular disease (CVD) (57). The potential of probiotics to support a reduction in inflammation markers in healthy adults has been discussed in the previous section. The effect of probiotics consumption on changes to blood lipid profile has been investigated in several systematic reviews and meta-analyses $(9,58-60)$. Collectively, findings from these reviews and metaanalyses suggest an improvement in blood lipid profile, especially in total cholesterol (TC) and LDL-C levels. However, these studies included both healthy and unhealthy adults (including conditions such as hypercholesterolemia, CVD, diabetes, obesity). Thus, conclusions regarding the influence of probiotics on the blood lipid profile of healthy adults cannot be reliably determined from this work.

A summary of results from the present review of literature for the effect of probiotics consumption on blood lipid profile of healthy adults is presented in Table 3. Of the fourteen studies (fifteen trials, one study with two separate arms (61)), seven reported no significant changes in the concentration of various blood lipid profile markers following probiotics consumption $(18,55,61-65)$. Three studies reported a significant reduction in TC (61, 66-68). Reductions in TG $(68-71)$, LDL-C $(61,66)$, and an increase in HDL-C $(67,68)$ were also reported. Furthermore, in one study, six weeks of probiotics treatment in healthy adults who were heavy smokers (55) demonstrated improvements in markers of oxidative stress $\left(\mathrm{F}_{2}-\right.$ isoprostanes) and the pro-inflammatory marker IL-6, supporting the cardio-protective effect of probiotics. Despite this, to date only a small number of individual studies have demonstrated benefits of probiotics and the collective evidence is not inclusive for the beneficial effect of probiotics consumption on blood lipid profile of healthy adults.

Changes in BMI were reported in six studies (Table 3). Of these four reported no significant changes $(18,55,67,71)$ and one reported a significant increase in BMI after probiotic supplementation (65). One of the studies assessed the BMI increase after four weeks of highfat diet and reported a lower increase in BMI in the probiotic group compared to placebo (72). Due to a low number of studies included and inconsistent results, a conclusion cannot be reached for the effect of probiotics on BMI of healthy adults. Seven studies also reported changes in fasting blood glucose (FBG) and insulin levels. Of these, four reported no significant changes in FBG or insulin levels $(55,64,71,72)$, two reported reduction in FBG 
and insulin level $(62,68)$ and one reported an increase in FBG after probiotics supplementation in healthy adults (65). Similar to BMI, the evidence is inconclusive for the beneficial effect of probiotics on FBG and insulin level in healthy adults.

Although underlying mechanisms of the effect of probiotics on lipid profile are not completely understood, the cholesterol binding and assimilation ability of probiotics and their ability to deconjugate bile salt (to reduce its solubility and absorbability) are proposed as the potential mechanisms of action (59). Bacteria in the gut also have the ability to produce shortchain fatty acids (SCFA) (such as acetate, butyrate and propionate) through fermentation of dietary fibers (73). SCFA are shown to lower hepatic cholesterol synthesis and regulate cholesterol metabolism (74). Both lactobacilli and bifidobacteria are able to produce SCFA. Recently proposed next generation of probiotics such as Akkermansia muciniphila and Faecalibacterium prausnitzii have also shown to have a high SCFA producing ability from dietary fibers $(75,76)$.

\section{Gastrointestinal discomfort}

Although constipation is often considered as a symptom of a health condition, irregularities in bowel movement, evacuation disorder, abdominal discomfort and bloating may occur in response to aging and changes in dietary, lifestyle and psychological factors in otherwise healthy individuals $(77,78)$. These changes also influence the bacterial flora of the intestine. A diet high in fat, for example, is known to cause dysbiosis in gut microbiota (79). Aging has also been associated with a decrease in the number and diversity of bifidobacteria (80). Benefits of probiotic supplementation in the treatment and management of many types of diarrhea and constipation have been reported in unhealthy populations $(7,8)$. Table 4 summarizes the evidence of the effect of probiotics consumption on GI health of healthy adults. Of the four studies included (six trials, two studies had two arms $(61,77)$ ), an improvement in the bowel movement, defection frequency and stool consistency was reported in five studies $(61,77,78)$. One study did not observe improvements in the colonic transit time or bowel movement (81). However, this study had the shortest duration of supplementation among the identified trials. Overall, it appears that probiotic supplementation may be effective at improving stool consistency, bowel movement and reducing irritation caused by abdominal bloating. The relevant mechanisms of probiotics in this action remain unclear. However, fermentation of non-digestible carbohydrates and production of short-chain fatty acids and carbon dioxide, removal of other intestinal gases 
(77) and the anti-inflammatory effect of probiotics have been suggested (8) as potential mechanisms.

\section{Female reproductive system health}

From birth until after puberty, lactobacilli are the predominant microorganisms populating the vaginal microbial environment (82). However, after puberty the microbial environment changes due to menstruation, hormonal changes, intercourse, infections and hygiene (83). This often results in a vaginal environment that is not predominant in lactobacilli bacteria for the majority of women (82), increasing susceptibility to urogenital infections such as urinary tract infection and bacterial vaginosis (84). The effect of probiotics supplementation on maintaining female reproductive health is summarised in Table 5. Four studies (five trials, one study had two arms (85)) have examined the effects of oral supplementation or vaginal suppositories with lactobacilli as a means of improving the vaginal environment. Among these four trials have suggested there was a significant increase in the level of vaginal lactobacilli $(82,85-87)$. Supplementation with L. acidophilus, L. rhamnosus or L. fermentum increased vaginal lactobacilli levels in healthy women $(82,85-87)$. The increase in vaginal lactobacilli population seems to prevent and reduce the incidence of vaginal infections in otherwise healthy adult women (83).

\section{Effect of probiotics on psychological health}

Although focus of this review thus far has been on physiological health outcomes, it is important to acknowledge that probiotics consumption may also influence psychological health - an essential domain of overall well-being. Conceptualization of the brain-gut axis has introduced a link between psychological health and gut microflora $(88,89)$.

Psychological distress can reduce the number and diversity of intestinal microorganisms by changing intestinal transit time, acidity, mucus secretion, stress hormones and immune response (88). Conversely, the gut microbiota can influence a hosts nervous system (gut-brain axis) by producing signalling molecules (e.g. polypeptides), modulating neuronal signalling mechanisms (88). A recent meta-analysis examining the effect of probiotics supplementation on depression score suggests that probiotics supplementation can induce a significant reduction in depression in both healthy adults and those with major depressive symptoms (90). Similarly, a recent systematic review and meta-analysis indicates significant improvement in subclinical symptoms (including reduced stress, depression and anxiety) can be achieved in healthy adults following probiotics supplementation (91). Collectively, 
evidence from these studies suggests that probiotics supplementation may improve psychological symptoms in healthy adults.

\section{Discussion}

Demand for probiotics food and supplements has increased over the past few decades. Globally, the probiotics market is expected to have up to an $8 \%$ compound annual growth rate increase from 2014 to 2020 (92). This prompts continued interest in research regarding the health benefits of probiotics. Although consumption of probiotics has beneficial effects on several health outcomes, the majority of findings are related to populations with specific health conditions or disease. This raises an important question as to whether the health benefits provided by probiotics are limited to individuals with underlying pathologies. Thus, in the current review, we explored the effects of probiotics consumption in otherwise healthy adults. Overall, results from this review suggest that probiotics supplementation in healthy adults generate an improvement in gut microbiota. However, despite gut microbiota changes occurring with probiotics, these changes appear to be limited to a transient increase in the bacterial count of the specific strain administered. This implies that supplementation with probiotics may need to be an ongoing process in order to maintain gut microbiota changes in healthy adults. Gut microbiota is sensitive to multiple factors, such as lifestyle, aging and disease. Even in apparently healthy individuals, changes in diet quality and alcohol intake can significantly affect gut symbiosis. A diet poor in fruit and vegetable intake (as a good source of prebiotics) may not provide the food required for probiotics survival and maintenance. This may explain the constant need for probiotic food and supplements to maintain gut symbiosis and health. Furthermore, in older adults with age-related dysbiosis, probiotic supplementation appears to improve and reduce dysbiosis.

The transient effect of probiotics on gut microbiota may also be explained by the viability of probiotic microorganisms. Evidence suggests that viability of probiotics could differ from the number of viable cells declared on the product label (93). Although drying processes during probiotic production may have a negative impact on viability, different drying methods (airdrying, freeze-drying and spray-drying) have diverse effects on probiotic strains in terms of both viability and functionality (94). Although viability is acknowledged as a prerequisite for the health benefits of probiotics, few interventions have reported the viability of probiotics during the period of supplementation. Evidence suggests that non-viable probiotic strains 
may also confer some positive health outcomes (93) however, this requires further investigation.

The current review also suggests that probiotics consumption in healthy adults may improve immune function, particularly in response to common upper respiratory infections; reducing their incidence and/or symptom severity. This is particularly important since improved immune function via probiotics may reduce the antibiotic needs in infections, thus reduce the risk of antibiotic resistance (95) - one of the greatest global threat of present decade (96). Probiotics may enhance the immune response by activating $\mathrm{T}$ lymphocyte cells, increasing NK cell activity and anti-inflammatory cytokines (e.g. IL-10) and reducing pro-inflammatory cytokines (e.g. IL-12 and IL14). These findings are in agreement with a recent meta-analysis (including both healthy and unhealthy populations) indicating that probiotics consumption may have a protective effect against the common cold (97). As gut microbiota is typically considered the first line of defense against pathogenic microorganisms in the intestine, maintaining symbiosis through regular consumption of probiotics foods and/or supplements is essential. This is particularly important in older adults, where age-related decreases in immune function (98) may increase vulnerability to a variety of infections.

The present review did not find sufficient evidence to support a blood lipid profile lowering effect of probiotics in healthy adults. These findings are in contrast with several systematic reviews and meta-analyses suggesting probiotics consumption facilitates improvements in blood lipids $(9,58-60)$. This disagreement is likely due to the inclusion of both healthy and unhealthy (participants with a high baseline level of blood lipids) populations, hence a greater opportunity for improvements in lipid profiles was afforded in these previous reviews. Similarly, BMI, FBG and insulin level of healthy adults were not significantly affected by probiotics consumption in the present review. These findings, however, are in contrast to previous systematic review and meta-analysis of the effect of probiotics on BMI (99) and FBG (13). This can be explained by the inclusion of participants with underlying pathologies (obese or diabetic). For example, Nikbakht, Khalesi (13) included trials with high and normal FBG participants with an overall significant effect of probiotics consumption on FBG reduction. However, their subgroup analysis results showed no significant changes in participants with normal FBG level. This can explain the findings of the current review reporting no significant effect of probiotics on FBG of healthy adults. 
The current review also found some evidence for the effect of probiotics as a means of relieving abdominal discomfort and improving bowel movement irregularities in healthy adults. Although probiotics have been reported as beneficial for these conditions (78), definitive conclusions cannot be made and further research is required to clarify these findings in healthy adult populations. Probiotics consumption also appears to offer some benefits in maintaining female reproductive health by improving the lactobacilli count of the vaginal environment to prevent urogenital infections. Again however, the low number of eligible studies included in this review suggest that further investigation is required to support any dietary guidance provided for these conditions.

Although the effect of probiotics supplementation on psychological symptoms of healthy adults was not thoroughly reviewed in this paper, results of recent meta-analyses suggest improvements in depression, stress and anxiety following probiotics supplementation (90, 91). However in most studies included in these meta-analyses, changes in gut flora were not reported. Furthermore, psychological symptoms are typically measured using subjective selfreported scales and questionnaires, with different scales often administered across studies. Thus, it is important to consider these limitations when translating the findings. Nevertheless, probiotics supplementation may confer psychological benefits in healthy individuals and further exploration of these effects is warranted.

To our knowledge, the present review is first to assess the evidence for a range of healthrelated outcomes of probiotics consumption in healthy adults. However, the present study does have some limitations. Firstly, it was not possible to employ a complete systematic review approach due to the differences in study design, participant characteristics and dependent measures included in this review. Therefore, it limited the potential of the review to assess the methodological quality and bias risk of included studies. However, of the 45 studies included in this review the majority were randomised $(n=38)$, included blinding $(n=32)$ and had similar control or placebo groups $(n=38)$. Secondly, the low number of studies included in the review of GI health and female reproductive health outcomes limits the conclusions that can be drawn from these research areas. Also, probiotics characteristics are strain-specific and due to variations in the probiotic strains used in the included studies, a conclusion cannot be made on the effective strains.

With ongoing increases in the manufacturing and marketing of probiotics to the general public there is a need for the benefits of probiotics to be better understood. Although this 
review suggests that healthy adults (and in particular, older adults) may achieve some health benefits from consistent use of probiotics, probiotics supplementation may have a similar fate to multivitamins. That is, they may be effective in specific cases or conditions. More research on the probiotics use is necessary to develop a stronger body of evidence for their efficacy across both healthy and unhealthy population groups. Additionally, interventions with followup periods are required to assess the sustainability of probiotics use and their effect in healthy adults. Until further research is conducted, the benefits and feasibility of probiotics consumption in healthy adults remain uncertain and it would be prudent to advise consumers that supplementation with probiotics may be more effective in specific population groups and those with underlying pathologies.

Acknowledgements: Authors declare there is no source of funding or for this study.

Conflicts of Interests: Authors declare that there is no conflict of interest.

\section{References}

1. McFarland LV. From yaks to yogurt: the history, development, and current use of probiotics. Clinical infectious diseases : an official publication of the Infectious Diseases Society of America. 2015;60 Suppl 2:S85-90.

2. Fuller R. Probiotics: an overview. Human Health: Springer; 1994. p. 63-73.

3. Metchnikoff II. The prolongation of life: optimistic studies: Springer Publishing Company; 2004.

4. FAO/WHO. Guidelines for the Evaluation of Probiotics in Food. London, Ontario, Canada2002.

5. Irwin C, Khalesi S, Cox AJ, Grant G, Davey AK, Bulmer AC, et al. Effect of 8-weeks prebiotics/probiotics supplementation on alcohol metabolism and blood biomarkers of healthy adults: a pilot study. Eur J Nutr. 2017.

6. Ferrario C, Taverniti V, Milani C, Fiore W, Laureati M, De Noni I, et al. Modulation of Fecal Clostridiales Bacteria and Butyrate by Probiotic Intervention with Lactobacillus paracasei DG Varies among Healthy Adults. The Journal of nutrition. 2014;144(11):1787-96.

7. Guarino A, Guandalini S, Lo Vecchio A. Probiotics for Prevention and Treatment of Diarrhea. J Clin Gastroenterol. 2015;49 Suppl 1:S37-45.

8. Ford AC, Quigley EM, Lacy BE, Lembo AJ, Saito YA, Schiller LR, et al. Efficacy of prebiotics, probiotics, and synbiotics in irritable bowel syndrome and chronic idiopathic constipation: systematic review and meta-analysis. Am J Gastroenterol. 2014;109(10):1547-61; quiz 6, 62.

9. Guo Z, Liu XM, Zhang QX, Shen Z, Tian FW, Zhang H, et al. Influence of consumption of probiotics on the plasma lipid profile: a meta-analysis of randomised controlled trials. Nutrition, metabolism, and cardiovascular diseases : NMCD. 2011;21(11):844-50.

10. Sun J, Buys N. Effects of probiotics consumption on lowering lipids and CVD risk factors: a systematic review and meta-analysis of randomized controlled trials. Annals of medicine. 2015;47(6):430-40. 
11. Nikbakht Nasrabadi E, Jamaluddin R, Mutalib A, Khaza'ai H, Khalesi S, Mohd Redzwan S. Reduction of aflatoxin level in aflatoxin-induced rats by the activity of probiotic Lactobacillus casei strain Shirota. Journal of applied microbiology. 2013;114(5):1507-15.

12. Khalesi S, Sun J, Buys N, Jayasinghe R. Effect of probiotics on blood pressure: A systematic review and meta-analysis of randomized, controlled trials. Hypertension (Dallas, Tex : 1979). 2014;64(4):897-903.

13. Nikbakht E, Khalesi S, Singh I, Williams LT, West NP, Colson N. Effect of probiotics and synbiotics on blood glucose: a systematic review and meta-analysis of controlled trials. European journal of nutrition. 2016.

14. Sun J, Buys NJ. Glucose- and glycaemic factor-lowering effects of probiotics on diabetes: a meta-analysis of randomised placebo-controlled trials. The British journal of nutrition. 2016;115(7):1167-77.

15. Foster JA, Lyte M, Meyer E, Cryan JF. Gut Microbiota and Brain Function: An Evolving Field in Neuroscience. The international journal of neuropsychopharmacology. 2016;19(5).

16. Kumar H, Salminen S, Verhagen H, Rowland I, Heimbach J, Bañares S, et al. Novel probiotics and prebiotics: road to the market. Current opinion in biotechnology. 2015;32:99-103.

17. Kristensen NB, Bryrup T, Allin KH, Nielsen T, Hansen TH, Pedersen O. Alterations in fecal microbiota composition by probiotic supplementation in healthy adults: a systematic review of randomized controlled trials. Genome medicine. 2016;8(1):52.

18. de Roos NM, Schouten G, Katan MB. Yoghurt enriched with Lactobacillus acidophilus does not lower blood lipids in healthy men and women with normal to borderline high serum cholesterol levels. European journal of clinical nutrition. 1999;53(4):277-80.

19. Moher D, Liberati A, Tetzlaff J, Altman DG. Preferred reporting items for systematic reviews and meta-analyses: the PRISMA statement. Annals of internal medicine. 2009;151(4):264-9.

20. Higgins JP, Green S. Cochrane handbook for systematic reviews of interventions: Wiley Online Library; 2008.

21. Plaza-Diaz J, Fernandez-Caballero JA, Chueca N, Garcia F, Gomez-Llorente C, Saez-Lara MJ, et al. Pyrosequencing analysis reveals changes in intestinal microbiota of healthy adults who received a daily dose of immunomodulatory probiotic strains. Nutrients. 2015;7(6):3999-4015.

22. Rampelli S, Candela M, Severgnini M, Biagi E, Turroni S, Roselli M, et al. A probioticscontaining biscuit modulates the intestinal microbiota in the elderly. The journal of nutrition, health \& aging. 2013;17(2):166-72.

23. Lahti L, Salonen A, Kekkonen RA, Salojärvi J, Jalanka-Tuovinen J, Palva A, et al. Associations between the human intestinal microbiota, Lactobacillus rhamnosus GG and serum lipids indicated by integrated analysis of high-throughput profiling data. PeerJ. 2013;1:e32.

24. Wind RD, Tolboom H, Klare I, Huys G, Knol J. Tolerance and safety of the potentially probiotic strain Lactobacillus rhamnosus PRSF-L477: a randomised, double-blind placebo-controlled trial in healthy volunteers. British Journal of Nutrition. 2010;104(12):1806-16.

25. Mai V, Waugh S, Byrd D, Simpson D, Ukhanova M. Novel encapsulation improves recovery of probiotic strains in fecal samples of human volunteers. Applied microbiology and biotechnology. 2017;101(4):1419-25.

26. Fontana L, Bermudez-Brito M, Plaza-Diaz J, Munoz-Quezada S, Gil A. Sources, isolation, characterisation and evaluation of probiotics. Br J Nutr. 2013;109 Suppl 2:S35-50.

27. Mainville I, Arcand Y, Farnworth ER. A dynamic model that simulates the human upper gastrointestinal tract for the study of probiotics. International journal of food microbiology. 2005;99(3):287-96.

28. Lo Curto A, Pitino I, Mandalari G, Dainty JR, Faulks RM, John Wickham MS. Survival of probiotic lactobacilli in the upper gastrointestinal tract using an in vitro gastric model of digestion. Food microbiology. 2011;28(7):1359-66.

29. Wang R, Chen S, Jin J, Ren F, Li Y, Qiao Z, et al. Survival of Lactobacillus casei strain Shirota in the intestines of healthy Chinese adults. Microbiology and immunology. 2015;59(5):268-76.

30. Kailasapathy K, Chin J. Survival and therapeutic potential of probiotic organisms with reference to Lactobacillus acidophilus and Bifidobacterium spp. Immunology and cell biology. 2000;78(1):80-8. 
31. Bezkorovainy A. Probiotics: determinants of survival and growth in the gut. The American journal of clinical nutrition. 2001;73(2):399s-405s.

32. Riaz QU, Masud T. Recent trends and applications of encapsulating materials for probiotic stability. Critical reviews in food science and nutrition. 2013;53(3):231-44.

33. Mortazavian AM, Mohammadi R, Sohrabvandi S. Delivery of probiotic microorganisms into gastrointestinal tract by food products: INTECH Open Access Publisher; 2012.

34. Kamada N, Chen GY, Inohara N, Núñez G. Control of Pathogens and Pathobionts by the Gut Microbiota. Nature immunology. 2013;14(7):685-90.

35. Gibson GR, Roberfroid MB. Dietary modulation of the human colonic microbiota: introducing the concept of prebiotics. The Journal of nutrition. 1995;125(6):1401.

36. Slavin J. Fiber and Prebiotics: Mechanisms and Health Benefits. Nutrients. 2013;5(4):1417-35.

37. Walton GE, van den Heuvel EG, Kosters MH, Rastall RA, Tuohy KM, Gibson GR. A randomised crossover study investigating the effects of galacto-oligosaccharides on the faecal microbiota in men and women over 50 years of age. The British journal of nutrition. 2012;107(10):1466-75.

38. Vulevic J, Juric A, Tzortzis G, Gibson GR. A mixture of trans-galactooligosaccharides reduces markers of metabolic syndrome and modulates the fecal microbiota and immune function of overweight adults. The Journal of nutrition. 2013;143(3):324-31.

39. Johnston BC, Ma SS, Goldenberg JZ, Thorlund K, Vandvik PO, Loeb M, et al. Probiotics for the prevention of Clostridium difficile-associated diarrhea: a systematic review and meta-analysis. Annals of internal medicine. 2012;157(12):878-88.

40. Woodmansey EJ, McMurdo MET, Macfarlane GT, Macfarlane S. Comparison of Compositions and Metabolic Activities of Fecal Microbiotas in Young Adults and in Antibiotic-Treated and Non-Antibiotic-Treated Elderly Subjects. Applied and Environmental Microbiology. 2004;70(10):6113-22.

41. Mariat D, Firmesse O, Levenez F, Guimaraes V, Sokol H, Dore J, et al. The Firmicutes/Bacteroidetes ratio of the human microbiota changes with age. BMC microbiology. 2009;9:123.

42. Rooks MG, Garrett WS. Gut microbiota, metabolites and host immunity. Nature reviews Immunology. 2016;16(6):341-52.

43. Baron M. A patented strain of Bacillus coagulans increased immune response to viral challenge. Postgraduate Medicine. 2009;121(2):114-8.

44. Berggren A, Lazou Ahrén I, Larsson N, Önning G. Randomised, double-blind and placebocontrolled study using new probiotic lactobacilli for strengthening the body immune defence against viral infections. European journal of nutrition. 2011;50(3):203-10.

45. Makino S, Ikegami S, Kume A, Horiuchi H, Sasaki H, Orii N. Reducing the risk of infection in the elderly by dietary intake of yoghurt fermented with Lactobacillus delbrueckii ssp. bulgaricus OLL1073R-1. The British journal of nutrition. 2010;104(7):998-1006.

46. de Vrese M, Winkler P, Rautenberg P, Harder T, Noah C, Laue C, et al. Effect of Lactobacillus gasseri PA 16/8, Bifidobacterium longum SP 07/3, B. bifidum MF 20/5 on common cold episodes: a double blind, randomized, controlled trial. Clinical Nutrition. 2005;24(4):481-91.

47. Jespersen L, Tarnow I, Eskesen D, Morberg CM, Michelsen B, Bügel S, et al. Effect of Lactobacillus paracasei subsp. paracasei, L. casei 431 on immune response to influenza vaccination and upper respiratory tract infections in healthy adult volunteers: a randomized, double-blind, placebo-controlled, parallel-group study. American Journal of Clinical Nutrition. 2015;101(6):1188-96.

48. Van Puyenbroeck K, Hens N, Coenen S, Michiels B, Beunckens C, Molenberghs G, et al. Efficacy of daily intake of Lactobacillus casei Shirota on respiratory symptoms and influenza vaccination immune response: a randomized, double-blind, placebo-controlled trial in healthy elderly nursing home residents. American Journal of Clinical Nutrition. 2012;95(5):1165-71.

49. West NP, Horn PL, Pyne DB, Gebski VJ, Lahtinen SJ, Fricker PA, et al. Probiotic supplementation for respiratory and gastrointestinal illness symptoms in healthy physically active individuals. Clinical Nutrition. 2014;33(4):581-7. 
50. Kekkonen RA, Vasankari TJ, Vuorimaa T, Haahtela T, Julkunen I, Korpela R. The effect of probiotics on respiratory infections and gastrointestinal symptoms during training in marathon runners. International Journal of Sport Nutrition \& Exercise Metabolism. 2007;17(4):352-63.

51. Harbige LS, Pinto E, Allgrove J, Thomas LV. Immune Response of Healthy Adults to the Ingested Probiotic Lactobacillus casei Shirota. Scandinavian journal of immunology. 2016;84(6):353-64.

52. Gill HS, Rutherfurd KJ, Cross ML, Gopal PK. Enhancement of immunity in the elderly by dietary supplementation with the probiotic Bifidobacterium lactis HN019. American Journal of Clinical Nutrition. 2001;74(6):833-9.

53. Dong H, Rowland I, Thomas LV, Yaqoob P. Immunomodulatory effects of a probiotic drink containing Lactobacillus casei Shirota in healthy older volunteers. European journal of nutrition. 2013;52(8):1853-63.

54. Parra MD, Martinez de Morentin BE, Cobo JM, Mateos A, Martinez JA. Daily ingestion of fermented milk containing Lactobacillus casei DN114001 improves innate-defense capacity in healthy middle-aged people. Journal of physiology and biochemistry. 2004;60(2):85-91.

55. Naruszewicz M, Johansson M, Zapolska-Downar D, Bukowska H. Effect of Lactobacillus plantarum $299 \mathrm{v}$ on cardiovascular disease risk factors in smokers. American Journal of Clinical Nutrition. 2002;76(6):1249-55.

56. Nyangale EP, Farmer S, Cash HA, Keller D, Chernoff D, Gibson GR. Bacillus coagulans GBI30, 6086 Modulates Faecalibacterium prausnitzii in Older Men and Women. The Journal of nutrition. 2015;145(7):1446-52.

57. DiRienzo DB. Effect of probiotics on biomarkers of cardiovascular disease: implications for heart-healthy diets. Nutrition reviews. 2014;72(1):18-29.

58. Shimizu M, Hashiguchi M, Shiga T, Tamura HO, Mochizuki M. Meta-Analysis: Effects of Probiotic Supplementation on Lipid Profiles in Normal to Mildly Hypercholesterolemic Individuals. PloS one. 2015;10(10):e0139795.

59. Cho YA, Kim J. Effect of Probiotics on Blood Lipid Concentrations: A Meta-Analysis of Randomized Controlled Trials. Medicine. 2015;94(43):e1714.

60. Wu Y, Zhang Q, Ren Y, Ruan Z. Effect of probiotic Lactobacillus on lipid profile: A systematic review and meta-analysis of randomized, controlled trials. PloS one. 2017;12(6):e0178868.

61. Higashikawa F, Noda M, Awaya T, Nomura K, Oku H, Sugiyama M. Improvement of constipation and liver function by plant-derived lactic acid bacteria: a double-blind, randomized trial. Nutrition (Burbank, Los Angeles County, Calif). 2010;26(4):367-74.

62. Cox AJ, West NP, Horn PL, Lehtinen MJ, Koerbin G, Pyne DB, et al. Effects of probiotic supplementation over 5 months on routine haematology and clinical chemistry measures in healthy active adults. European journal of clinical nutrition. 2014;68(11):1255-7.

63. Greany KA, Bonorden MJ, Hamilton-Reeves JM, McMullen MH, Wangen KE, Phipps WR, et al. Probiotic capsules do not lower plasma lipids in young women and men. European journal of clinical nutrition. 2008;62(2):232-7.

64. Rizkalla SW, Luo J, Kabir M, Chevalier A, Pacher N, Slama G. Chronic consumption of fresh but not heated yogurt improves breath-hydrogen status and short-chain fatty acid profiles: a controlled study in healthy men with or without lactose maldigestion. American Journal of Clinical Nutrition. 2000;72(6):1474-9.

65. Irwin C, Khalesi S, Cox AJ, Grant G, Davey AK, Bulmer AC, et al. Effect of 8-Weeks Prebiotics/Probiotics Supplementation on Alcohol Metabolism and Blood Biomarkers of Healthy Adults: A Pilot Study. European journal of nutrition. 2017; doi: 10.1007/s00394-017-1437-8.

66. Agerbaek M, Gerdes LU, Richelsen B. Hypocholesterolaemic effect of a new fermented milk product in healthy middle-aged men. European journal of clinical nutrition. 1995;49(5):346-52.

67. Sadrzadeh-Yeganeh H, Elmadfa I, Djazayery A, Jalali M, Heshmat R, Chamary M. The effects of probiotic and conventional yoghurt on lipid profile in women. The British journal of nutrition. 2010;103(12):1778-83.

68. Rajkumar H, Mahmood N, Kumar M, Varikuti SR, Challa HR, Myakala SP. Effect of Probiotic (VSL\#3) and Omega-3 on Lipid Profile, Insulin Sensitivity, Inflammatory Markers, and Gut Colonization in Overweight Adults: A Randomized, Controlled Trial. Mediators of Inflammation. 2014;2014:348959. 
69. Bjerg AT, Sorensen MB, Krych L, Hansen LH, Astrup A, Kristensen M, et al. The effect of Lactobacillus paracasei subsp. paracasei L. casei W8(R) on blood levels of triacylglycerol is independent of colonisation. Beneficial microbes. 2015;6(3):263-9.

70. Klein A, Friedrich U, Vogelsang H, Jahreis G. Lactobacillus acidophilus 74-2 and Bifidobacterium animalis subsp lactis DGCC 420 modulate unspecific cellular immune response in healthy adults. European journal of clinical nutrition. 2008;62(5):584-93.

71. Hulston CJ, Churnside AA, Venables MC. Probiotic supplementation prevents high-fat, overfeeding-induced, insulin resistance in humans. The British journal of nutrition. 2015;113(4):596-602.

72. Osterberg KL, Boutagy NE, McMillan RP, Stevens JR, Frisard MI, Kavanaugh JW, et al. Probiotic supplementation attenuates increases in body mass and fat mass during high-fat diet in healthy young adults. Obesity. 2015;23(12):2364-70.

73. LeBlanc JG, Chain F, Martín R, Bermúdez-Humarán LG, Courau S, Langella P. Beneficial effects on host energy metabolism of short-chain fatty acids and vitamins produced by commensal and probiotic bacteria. Microbial Cell Factories. 2017;16:79.

74. den Besten G, van Eunen K, Groen AK, Venema K, Reijngoud D-J, Bakker BM. The role of short-chain fatty acids in the interplay between diet, gut microbiota, and host energy metabolism. Journal of Lipid Research. 2013;54(9):2325-40.

75. Derrien M, Collado MC, Ben-Amor K, Salminen S, de Vos WM. The Mucin degrader Akkermansia muciniphila is an abundant resident of the human intestinal tract. Appl Environ Microbiol. 2008;74(5):1646-8.

76. Derrien M, Vaughan EE, Plugge CM, de Vos WM. Akkermansia muciniphila gen. nov., sp. nov., a human intestinal mucin-degrading bacterium. Int J Syst Evol Microbiol. 2004;54(Pt 5):146976.

77. Del Piano M, Carmagnola S, Anderloni A, Andorno S, Ballarè M, Balzarini M, et al. The use of probiotics in healthy volunteers with evacuation disorders and hard stools: a double-blind, randomized, placebo-controlled study. Journal of Clinical Gastroenterology. 2010;44:S30-4.

78. Sakai T, Makino H, Ishikawa E, Oishi K, Kushiro A. Fermented milk containing Lactobacillus casei strain Shirota reduces incidence of hard or lumpy stools in healthy population. International Journal of Food Sciences \& Nutrition. 2011;62(4):423-30.

79. Murphy EA, Velazquez KT, Herbert KM. Influence of High-Fat-Diet on Gut Microbiota: A Driving Force for Chronic Disease Risk. Current opinion in clinical nutrition and metabolic care. 2015;18(5):515-20.

80. Biagi E, Candela M, Fairweather-Tait S, Franceschi C, Brigidi P. Ageing of the human metaorganism: the microbial counterpart. Age. 2012;34(1):247-67.

81. Merenstein DJ, D'Amico F, Palese C, Hahn A, Sparenborg J, Tan T, et al. Short-term, daily intake of yogurt containing Bifidobacterium animalis ssp. lactis Bf-6 (LMG 24384) does not affect colonic transit time in women. The British journal of nutrition. 2014;111(2):279-86.

82. Verdenelli MC, Cecchini C, Coman MM, Silvi S, Orpianesi C, Coata G, et al. Impact of Probiotic SYNBIO((R)) Administered by Vaginal Suppositories in Promoting Vaginal Health of Apparently Healthy Women. Current microbiology. 2016;73(4):483-90.

83. Recine N, Palma E, Domenici L, Giorgini M, Imperiale L, Sassu C, et al. Restoring vaginal microbiota: biological control of bacterial vaginosis. A prospective case-control study using Lactobacillus rhamnosus BMX 54 as adjuvant treatment against bacterial vaginosis. Archives of Gynecology \& Obstetrics. 2016;293(1):101-7.

84. Borges S, Silva J, Teixeira $\mathrm{P}$. The role of lactobacilli and probiotics in maintaining vaginal health. Archives of gynecology and obstetrics. 2014;289(3):479-89.

85. Reid G, Beuerman D, Heinemann C, Bruce AW. Probiotic Lactobacillus dose required to restore and maintain a normal vaginal flora. FEMS immunology and medical microbiology. 2001;32(1):37-41.

86. De Alberti D, Russo R, Terruzzi F, Nobile V, Ouwehand AC. Lactobacilli vaginal colonisation after oral consumption of Respecta( $(\mathrm{R}))$ complex: a randomised controlled pilot study. Archives of gynecology and obstetrics. 2015;292(4):861-7.

87. Reid G, Charbonneau D, Erb J, Kochanowski B, Beuerman D, Poehner R, et al. Oral use of Lactobacillus rhamnosus GR-1 and L. fermentum RC-14 significantly alters vaginal flora: 
randomized, placebo-controlled trial in 64 healthy women. FEMS immunology and medical microbiology. 2003;35(2):131-4.

88. Rhee SH, Pothoulakis C, Mayer EA. Principles and clinical implications of the brain-gut-enteric microbiota axis. Nature reviews Gastroenterology \& hepatology. 2009;6(5):306-14.

89. Takada M, Nishida K, Kataoka-Kato A, Gondo Y, Ishikawa H, Suda K, et al. Probiotic Lactobacillus casei strain Shirota relieves stress-associated symptoms by modulating the gutbrain interaction in human and animal models. Neurogastroenterology and motility : the official journal of the European Gastrointestinal Motility Society. 2016;28(7):1027-36.

90. Huang R, Wang K, Hu J. Effect of Probiotics on Depression: A Systematic Review and MetaAnalysis of Randomized Controlled Trials. Nutrients. 2016;8(8).

91. McKean J, Naug H, Nikbakht E, Amiet B, Colson N. Probiotics and Subclinical Psychological Symptoms in Healthy Participants: A Systematic Review and Meta-Analysis. Journal of alternative and complementary medicine (New York, NY). 2017;23(4):249-58.

92. Transparency Market Research. Probiotic Market By Application ( Food and Beverages ,Dietary Supplements , Animal Feed) By End Users (Human Probiotics, Animal Probiotics)-Global Industry Analysis, Size, Share, Growth and Forecast 2014 - 20202015 [Available from: https://www.transparencymarketresearch.com/probiotics-market.html.

93. Lahtinen SJ. Probiotic viability - does it matter? Microb Ecol Health Dis. 2012;23.

94. Iaconelli C, Lemetais G, Kechaou N, Chain F, Bermudez-Humaran LG, Langella P, et al. Drying process strongly affects probiotics viability and functionalities. J Biotechnol. 2015;214:17-26.

95. Ouwehand AC, Forssten S, Hibberd AA, Lyra A, Stahl B. Probiotic approach to prevent antibiotic resistance. Annals of medicine. 2016;48(4):246-55.

96. Conly J, Johnston B. Where are all the new antibiotics? The new antibiotic paradox. The Canadian journal of infectious diseases \& medical microbiology = Journal canadien des maladies infectieuses et de la microbiologie medicale. 2005;16(3):159-60.

97. Kang E-J, Kim SY, Hwang I-H, Ji Y-J. The Effect of Probiotics on Prevention of Common Cold: A Meta-Analysis of Randomized Controlled Trial Studies. Korean Journal of Family Medicine. 2013;34(1):2-10.

98. Montecino-Rodriguez E, Berent-Maoz B, Dorshkind K. Causes, consequences, and reversal of immune system aging. The Journal of Clinical Investigation. 2013;123(3):958-65.

99. Zhang Q, Wu Y, Fei X. Effect of probiotics on body weight and body-mass index: a systematic review and meta-analysis of randomized, controlled trials. International journal of food sciences and nutrition. 2015;67(5):571-80.

100. Brown AC, Shovic A, Ibrahim SA, Holck P, Huang A, Brown AC, et al. A non-dairy probiotic's (poi) influence on changing the gastrointestinal tract's microflora environment. Alternative Therapies in Health \& Medicine. 2005;11(1):58-64.

101. Guillemard E, Tondu F, Lacoin F, Schrezenmeir J. Consumption of a fermented dairy product containing the probiotic Lactobacillus casei DN-114001 reduces the duration of respiratory infections in the elderly in a randomised controlled trial. The British journal of nutrition. 2010;103(1):58-68.

102. Hanifi A, Culpepper T, Mai V, Anand A, Ford AL, Ukhanova M, et al. Evaluation of Bacillus subtilis R0179 on gastrointestinal viability and general wellness: a randomised, double-blind, placebo-controlled trial in healthy adults. Beneficial microbes. 2015;6(1):19-27.

103. Wassenaar TM, Beimfohr C, Geske T, Zimmermann K. Voluntarily exposure to a single, high dose of probiotic Escherichia coli results in prolonged colonisation. Beneficial microbes. 2014;5(4):367-75. 


\section{Figure Legends:}

Figure.1 Flow diagram of the review process for the effect of probiotic supplementation in healthy adults

Table 1. Characteristics of included studies for the effect of probiotics on gut microbiota changes

\begin{tabular}{|c|c|c|c|c|c|}
\hline Study (year) & $\begin{array}{l}\text { Design; } \\
\text { Location }\end{array}$ & $\begin{array}{l}\text { Intervention/ } \\
\text { Control, } \\
\text { supplement }\end{array}$ & $\begin{array}{l}\text { Duration; } \\
\text { Age; } \\
\text { participants } \\
(\mathbf{m} / \mathbf{f})\end{array}$ & $\begin{array}{l}\text { Probiotic; Dose } \\
\text { (per day), CFU }\end{array}$ & $\begin{array}{l}\text { Outcome effect; reported side- } \\
\text { effects }\end{array}$ \\
\hline $\begin{array}{l}\text { Bjerg, et al. } \\
2015(69)\end{array}$ & $\begin{array}{l}\mathrm{RC}, \mathrm{DB}, \\
\mathrm{P}, \\
\text { Denmark }\end{array}$ & $\begin{array}{l}\text { Probiotic } \\
\text { capsule/ } \\
\text { placebo }\end{array}$ & $\begin{array}{l}4 \text { wk; } 20-54 \\
y ; 64(32 / 32)\end{array}$ & L. casei; $1.0 \times 10^{10}$ & $\begin{array}{l}\text { Significant increase in the specific } \\
\text { strain after intervention but no } \\
\text { effect on overall composition of } \\
\text { gut }\end{array}$ \\
\hline $\begin{array}{l}\text { Brown, et al. } \\
2005(100)\end{array}$ & $\begin{array}{l}\mathrm{CO}, \mathrm{RC} \\
\mathrm{USA}\end{array}$ & $\begin{array}{l}\text { Poi probiotics } \\
\text { drink (non- } \\
\text { dairy based)/ } \\
\text { control }\end{array}$ & $\begin{array}{l}14 \mathrm{wk} ; 18- \\
64 \mathrm{y} ; 18 \\
(8 / 10)\end{array}$ & $\begin{array}{l}\text { L. lactic }+L \text {. } \\
\text { streptococcus; } 1.9- \\
3.9 \times 10^{8}\end{array}$ & $\begin{array}{l}\text { No significant change in the total } \\
\text { concentration of gut bacteria; No } \\
\text { side-effects }\end{array}$ \\
\hline $\begin{array}{l}\text { Ferrario, et } \\
\text { al. } 2014(6)\end{array}$ & $\begin{array}{l}\mathrm{CO}, \mathrm{RC} \\
\mathrm{DB} ; \text { Italy }\end{array}$ & $\begin{array}{l}\text { Probiotic } \\
\text { supplements/ } \\
\text { placebo }\end{array}$ & $\begin{array}{l}4 \text { wk; } 23-55 \\
y ; 34(19 / 15)\end{array}$ & $\begin{array}{l}\text { L. paracasei } D G \text {; } \\
2.4 \times 10^{10}\end{array}$ & $\begin{array}{l}\text { Significant increase in healthy } \\
\text { bacteria genus, and reduction in } \\
\text { bacteria associated with disease } \\
\text { (reduction in Blautia:Coprococcus } \\
\text { ratio); No side-effects }\end{array}$ \\
\hline $\begin{array}{l}\text { Guillemard, } \\
\text { et al. } 2010 \\
(101)\end{array}$ & $\begin{array}{l}\mathrm{RC} ; \mathrm{DB} ; \\
\mathrm{P} ; \text { France }\end{array}$ & $\begin{array}{l}\text { Fermented dairy } \\
\text { drink/ placebo } \\
\text { drink }\end{array}$ & $\begin{array}{l}12 \mathrm{wk} ; 72- \\
80 \mathrm{y} ; 537 \\
(198 / 339)\end{array}$ & $\begin{array}{l}\text { L. paracasei }(L . \\
\text { casei })+S . \\
\text { thermophilus }+L . \\
\text { bulgaricus } 1.0 \times 10^{9}\end{array}$ & $\begin{array}{l}\text { Significant increase in specific } \\
\text { strain during probiotics } \\
\text { consumption. }\end{array}$ \\
\hline $\begin{array}{l}\text { Hanifi, et al. } \\
2015(102)\end{array}$ & $\begin{array}{l}\mathrm{RC}, \mathrm{DB} \\
\mathrm{P}, \mathrm{USA}\end{array}$ & $\begin{array}{l}\text { Probiotic } \\
\text { capsule/ } \\
\text { placebo }\end{array}$ & $\begin{array}{l}4 \text { wk; } 18-50 \\
y ; 81(40 / 41)\end{array}$ & B. subtilis; $1.0 \times 10^{10}$ & $\begin{array}{l}\text { Significant increase in the specific } \\
\text { strain after intervention; No side- } \\
\text { effect }\end{array}$ \\
\hline $\begin{array}{l}\text { Irwin, et al. } \\
2017(65)\end{array}$ & $\begin{array}{l}\mathrm{P}, \mathrm{RC} \\
\mathrm{DB} \\
\text { Australia }\end{array}$ & $\begin{array}{l}\text { Probiotic } \\
\text { supplements/ } \\
\text { placebo }\end{array}$ & $\begin{array}{l}8 \text { wk: } 26.2 \pm \\
8.4 \mathrm{y} ; 19 \\
(10 / 9)\end{array}$ & $\begin{array}{l}\text { L.acidophilus }+B \text {. } \\
\text { lactis; } 2.5 \times 10^{10}\end{array}$ & $\begin{array}{l}\text { Increase in faecal count of specific } \\
\text { strains after intervention. Some GI } \\
\text { discomfort }\end{array}$ \\
\hline $\begin{array}{l}\text { Klein, et al. } \\
2008(70)\end{array}$ & $\begin{array}{l}\mathrm{P}, \mathrm{RC} \\
\mathrm{CO} \\
\text { Germany }\end{array}$ & $\begin{array}{l}\text { Probiotic } \\
\text { yoghurt/ } \\
\text { placebo }\end{array}$ & $\begin{array}{l}5 w k ; 25 \pm 3 \\
y ; 26(13 / 13)\end{array}$ & $\begin{array}{l}\text { L.acidophilus }+B \text {. } \\
\text { lactis; } 9.4 \times 10^{8}\end{array}$ & $\begin{array}{l}\text { Significant increase in the specific } \\
\text { strain after intervention; }\end{array}$ \\
\hline $\begin{array}{l}\text { Lahti, et al. } \\
2013(23)\end{array}$ & $\begin{array}{l}\mathrm{RC}, \mathrm{DB}, \\
\mathrm{P}, \text { Finland }\end{array}$ & $\begin{array}{l}\text { Probiotic } \\
\text { drink/ placebo }\end{array}$ & $\begin{array}{l}3 \text { wk; } 23-44 \\
y ; 25(7 / 18)\end{array}$ & $\begin{array}{l}\text { L. rhamnosus GG; } \\
1.5 \times 10^{10}\end{array}$ & $\begin{array}{l}\text { Significant increase in the specific } \\
\text { strain after intervention, reduced } \\
\text { to pre-treatment } 3 \text { weeks follow- } \\
\text { up }\end{array}$ \\
\hline
\end{tabular}




\begin{tabular}{|c|c|c|c|c|c|}
\hline $\begin{array}{l}\text { Mai, et al. } \\
2017 \text { (25) }\end{array}$ & $\begin{array}{l}\mathrm{P}, \mathrm{RC}, \\
\mathrm{DB}, \mathrm{USA}\end{array}$ & $\begin{array}{l}\text { Probiotics } \\
\text { capsules in } \\
\text { gelatin or } \\
\text { Pearls }\end{array}$ & $12 \mathrm{dy} ; 12$ & $\begin{array}{l}\text { L. acidophilus }+B \text {. } \\
\text { longum; } 1 \times 10^{9}\end{array}$ & $\begin{array}{l}\text { Significant increase in fecal count } \\
\text { of specific strains after } \\
\text { intervention }\end{array}$ \\
\hline $\begin{array}{l}\text { Nyangale, et } \\
\text { al. } 2015 \text { (56) }\end{array}$ & $\begin{array}{l}\text { RC, DB, } \\
\text { P; UK }\end{array}$ & $\begin{array}{l}\text { Probiotic } \\
\text { capsule }\end{array}$ & $\begin{array}{l}28 \mathrm{dy} ; 65- \\
80 \mathrm{y} ; 36917 / \\
25)\end{array}$ & $\begin{array}{l}\text { B. coagulans; } \\
1.0 \times 10^{9}\end{array}$ & $\begin{array}{l}\text { Significant increase in } \\
\text { Facalibacterium and Bacillus } \\
\text { coagulans; }\end{array}$ \\
\hline $\begin{array}{l}\text { Plaza-Diaz, } \\
\text { et al. } 2015 \\
\text { (21) }\end{array}$ & $\begin{array}{l}\mathrm{RC}, \mathrm{P} \\
\text { Spain }\end{array}$ & $\begin{array}{l}\text { Probiotic } \\
\text { capsule/ } \\
\text { placebo }\end{array}$ & $\begin{array}{l}30 \mathrm{dy} ; 20- \\
35 \mathrm{y} ; 23 \\
(14 / 9)\end{array}$ & $\begin{array}{l}\text { B. breve }+L \text {. } \\
\text { rhamnosus or } L \text {. } \\
\text { paracasei/ B. brevel } \\
\text { L. rhamnosus } \\
\text { separately; } 9 \times 10^{9}\end{array}$ & $\begin{array}{l}\text { Significant increase in faecal count } \\
\text { of specific strains after } \\
\text { intervention. L. rhamnosus } \\
\text { increased all Lactobacillus genus. } \\
\text { Most changes remained after } 15 \\
\text { days follow-up. }\end{array}$ \\
\hline $\begin{array}{l}\text { Rampelli, et } \\
\text { al. } 2013 \text { (22) }\end{array}$ & $\begin{array}{l}\mathrm{RC}, \mathrm{DB}, \\
\mathrm{P}, \\
\text { Italy }\end{array}$ & $\begin{array}{l}\text { Probiotic } \\
\text { biscuit/ } \\
\text { placebo }\end{array}$ & $\begin{array}{l}30 \mathrm{dy} ; 71- \\
88 \mathrm{y} ; 32 \\
(13 / 19)\end{array}$ & $\begin{array}{l}\text { B. longum }+L . \\
\text { helveticus; } 1.0 \times 10^{9}\end{array}$ & $\begin{array}{l}\text { Reduced the pathogen bacteria } \\
\text { (i.e. Clostridium cluster Xi, C. } \\
\text { difficile, } C . \text { perfringens, E. } \\
\text { faecium) and increase in the } \\
\text { probiotics B. longum and } \\
\text { Lactobacillaceae. Improved age- } \\
\text { related changes in gut microbiota }\end{array}$ \\
\hline $\begin{array}{l}\text { Wang, et al. } \\
2015 \text { (29) }\end{array}$ & SA, China & $\begin{array}{l}\text { Probiotic } \\
\text { drink }\end{array}$ & $\begin{array}{l}14 \mathrm{dy} ; 20- \\
40 \mathrm{y} ; 25 \\
(9 / 16)\end{array}$ & $\begin{array}{l}\text { L. casei Shirota; } \\
1.0 \times 10^{10}\end{array}$ & $\begin{array}{l}\text { Significant increase in faecal count } \\
\text { of specific strain after } \\
\text { intervention. The count decreased } \\
\text { after follow-up but remained } \\
\text { higher than baseline; No side- } \\
\text { effects }\end{array}$ \\
\hline $\begin{array}{l}\text { Wassenaar, } \\
\text { et al. } 2014 \\
\text { (103) }\end{array}$ & $\begin{array}{l}\text { SA, } \\
\text { Germany }\end{array}$ & $\begin{array}{l}\text { Probiotic } \\
\text { capsule }\end{array}$ & $\begin{array}{l}\text { Single dose; } 5 \\
(3 / 2)\end{array}$ & $\begin{array}{l}\text { E. coli } \mathrm{G} 1 / 2, \mathrm{G} 3 / 10 \text {, } \\
\text { G4/9, G6/7, G5 and } \\
\text { G8; } 2 \times 10^{9}\end{array}$ & $\begin{array}{l}\text { High colonization of the specific } \\
\text { strains for a period of } 10-30 \text { weeks } \\
\text { after single dose; Mild GI } \\
\text { discomfort }\end{array}$ \\
\hline $\begin{array}{l}\text { Wind, et al. } \\
2010(24)\end{array}$ & $\begin{array}{l}\mathrm{RC}, \mathrm{DB}, \\
\mathrm{P} \text {, The } \\
\text { Netherlan } \\
\text { ds }\end{array}$ & $\begin{array}{l}\text { Probiotics } \\
\text { sachets/ } \\
\text { placebo }\end{array}$ & $\begin{array}{l}3 \text { wk; } 42 \pm 16 \\
\text { y; } 34(14 / 20)\end{array}$ & $\begin{array}{l}\text { L. rhamnosus; } \\
1.0 \times 10^{11}\end{array}$ & $\begin{array}{l}\text { Significant increase in the specific } \\
\text { strain after supplementation, } \\
\text { reduced back to pre-intervention } \\
\text { within } 1 \text { week follow-up; No side- } \\
\text { effects }\end{array}$ \\
\hline
\end{tabular}

CO: cross-over; DB: double blind; P: parallel; RC: randomized controlled trial; SA: single arm 
Table 2. Characteristics of included studies for the effect of probiotics on immune system response

\begin{tabular}{|c|c|c|c|c|c|}
\hline Study (year) & $\begin{array}{l}\text { Design; } \\
\text { Location }\end{array}$ & $\begin{array}{l}\text { Intervention/ } \\
\text { Control }\end{array}$ & $\begin{array}{l}\text { Duration; } \\
\text { Age; } \\
\text { participants } \\
(\mathrm{m} / \mathrm{f})\end{array}$ & $\begin{array}{l}\text { Probiotic; Dose } \\
\text { (per day), CFU }\end{array}$ & $\begin{array}{l}\text { Outcome effect; reported side- } \\
\text { effects }\end{array}$ \\
\hline
\end{tabular}

\begin{tabular}{|c|c|c|c|c|}
\hline $\begin{array}{l}\text { Baron } 2009 \\
(43)\end{array}$ & SA, USA & $\begin{array}{l}\text { Probiotic } \\
\text { capsule }\end{array}$ & $\begin{array}{l}30 \mathrm{dy} ; 33- \\
63 \mathrm{y} ; 10 \\
(5 / 5)\end{array}$ & $\begin{array}{l}\text { B. coagulans; } \\
2.0 \times 10^{9}\end{array}$ \\
\hline $\begin{array}{l}\text { Berggren, et } \\
\text { al. } 2011 \text { (44) }\end{array}$ & $\begin{array}{l}\mathrm{RC}, \mathrm{DB}, \\
\mathrm{P} \text {; Sweden }\end{array}$ & $\begin{array}{l}\text { Probiotics } \\
\text { capsule/ } \\
\text { Placebo }\end{array}$ & $\begin{array}{l}12 \mathrm{wk} ; 18- \\
65 \mathrm{y} ; 318 \\
(180 / 92)\end{array}$ & $\begin{array}{l}\text { L. plantarum }+L \text {. } \\
\text { paracasei; } 1.0 \times 10\end{array}$ \\
\hline $\begin{array}{l}\text { de Vrese, et } \\
\text { al. } 2005(46)\end{array}$ & $\begin{array}{l}\mathrm{RC}, \mathrm{DB}, \\
\mathrm{P} ; \\
\text { Germany }\end{array}$ & $\begin{array}{l}\text { Probiotics with } \\
\text { multivitamin/ } \\
\text { multivitamin }\end{array}$ & $\begin{array}{l}12 \mathrm{wk} ; 36 \pm \\
13 \mathrm{y} ; 242 \\
(94 / 148)\end{array}$ & $\begin{array}{l}\text { L. Gasseri }+B . \\
\text { longum }+B . \\
\text { bifidum; } 5.0 \times 10^{7}\end{array}$ \\
\hline
\end{tabular}

Significant increase in TNF- $\alpha$ after in vitro exposure of $\mathrm{T}$ cells to flu A; No side-effects

Significant reduction in the incidence of common cold, the duration and the symptoms of common cold. Reduction in inflammatory B lymphocytes

Significant reduction in the duration and symptoms of common cold, and days with fever. Increase in $\mathrm{CD} 8+$ and $\mathrm{CD} 4+$ immune cells

$\begin{array}{lllll}\text { Dong, et al. } & \mathrm{RC}, \mathrm{SB}, & \text { Probiotic drink/ } & 4 \mathrm{wk} ; 55- & \text { L. casei Shirota; } \\ \text { 2013(53) } & \text { CO; UK } & \text { placebo drink } & \begin{array}{l}74 \mathrm{y} ; 30 \\ (12 / 18)\end{array} & 1.3 \times 10^{10}\end{array}$

$\begin{array}{llll}\text { Gill, et al. } & \text { SA; New } & \text { Probiotics milk } & \begin{array}{l}3 \mathrm{wk} ; 63- \\ 84 \mathrm{y} ; 30\end{array} \\ \text { 2001 (52) } & \text { Zealand } & & \text { B. lactis; } 5.0 \times 10^{10} \\ & & & \end{array}$

Significant increase in NK cell activity and CD25 in T cells. A trend toward increase in antiinflammatory cytokine IL-10 to pro-inflammatory IL-12

Increase in CD4+; CD25+ and NK cells. Increase in the in vitro phagocytose and tumoricidal activity of natural killer cells

Guillemard, RC; DB; et al. $2010 \quad P$; France (101)

Fermented dairy $12 \mathrm{wk} ; 72-$ drink/ placebo drink

\section{$80 \mathrm{y} ; 537$}

$(198 / 339)$

Harbige, et al. 2016 (51)

SA; UK

Probiotic drink

8 wk; 18 $49 \mathrm{y} ; 14$ (6/8)

L. paracasei $(L$. casei) $+S$. thermophilus $+L$. bulgaricus $1.0 \times 10^{9}$

L. casei Shirota; $6.5 \times 10^{9}$

Jespersen, et RC, DB, al. 2015 (47) $P$;

Denmark

Probiotic drink/

$6 \mathrm{wk} ; 18-$

$60 \mathrm{y} ; 1104$

$(453 / 651)$

L. paracasei (L. casei); $1.0 \times 10^{9}$

12 wk; $22-$ $69 \mathrm{y} ; 141$ $(125 / 16)$

Kekkonen, RC, DB, Probiotic drink/ placebo

L. rhamnosus GG; $4.0 \times 10^{10}$
Decreased duration of upper respiratory tract infection. No differences in the severity of symptoms.

Significant increase in $\mathrm{T}$ cell activation markers and $\mathrm{NK}$ cell markers. Significant reduction in inflammatory makers IL-12 and IL-4 and pro-inflammatory cytokines

No effect of probiotics on immune response to flu vaccine. No effect on severity or incidence of flu symptoms. A shorter duration of symptoms

No significant effect on incidence of respiratory infection or GIsymptoms, but shortened the duration of symptoms in healthy marathon runners 


\begin{tabular}{|c|c|c|c|c|c|}
\hline $\begin{array}{l}\text { Klein, et al. } \\
2008 \text { (70) }\end{array}$ & $\begin{array}{l}\mathrm{P}, \mathrm{RC} \\
\mathrm{CO} ; \\
\text { Germany }\end{array}$ & $\begin{array}{l}\text { Probiotic } \\
\text { yoghurt/ } \\
\text { placebo }\end{array}$ & $\begin{array}{l}5 \mathrm{wk} ; 25 \pm 3 \\
\mathrm{y} ; 26(13 / 13)\end{array}$ & $\begin{array}{l}\text { L.acidophilus }+B \text {. } \\
\text { lactis } ; 9.4 \times 10^{8}\end{array}$ & $\begin{array}{l}\text { Significant increase in the } \\
\text { phagocytic activity of monocytes } \\
\text { and granulocytes, but no change in } \\
\text { the level of inflammatory markers }\end{array}$ \\
\hline $\begin{array}{l}\text { Makino, et } \\
\text { al. } 2010 \\
(45) \mathbf{a}\end{array}$ & $\begin{array}{l}\mathrm{P} ; \mathrm{R} ; \\
\text { Japan }\end{array}$ & $\begin{array}{l}\text { Probiotic } \\
\text { yoghurt/ } \\
\text { placebo }\end{array}$ & $\begin{array}{l}8-12 \text { wk; } 59 \\
-84 \text { y; } 92\end{array}$ & $\begin{array}{l}\text { L. bulgaricus }+S . \\
\text { Thermophiles; } 2.0- \\
8.8 \times 10^{8}\end{array}$ & $\begin{array}{l}\text { Significant reduction in the risk of } \\
\text { catching cold, and increase in NK } \\
\text { cells activity }\end{array}$ \\
\hline $\begin{array}{l}\text { Naruszewic, } \\
\text { et al. } 2002 \\
(55)\end{array}$ & $\begin{array}{l}\mathrm{RC}, \mathrm{DB}, \\
\mathrm{P} ; \text { Sweden }\end{array}$ & $\begin{array}{l}\text { Probiotic drink/ } \\
\text { placebo }\end{array}$ & $\begin{array}{l}6 \mathrm{wk} ; 35- \\
45 \mathrm{y} ; 36 \\
(18 / 18)\end{array}$ & $\begin{array}{l}\text { L. plantarum; } \\
2.0 \times 10^{10}\end{array}$ & $\begin{array}{l}\text { Significant reduction in markers of } \\
\text { oxidative stress ( } \mathrm{F}_{2} \text {-isoprostanes) } \\
\text { and pro-inflammatory marker IL-6 } \\
\text { in heavy smokers }\end{array}$ \\
\hline $\begin{array}{l}\text { Nyangale, et } \\
\text { al. } 2015(56)\end{array}$ & $\begin{array}{l}\text { RC, DB, } \\
\text { P; UK }\end{array}$ & $\begin{array}{l}\text { Probiotic } \\
\text { capsule/ placebo }\end{array}$ & $\begin{array}{l}28 \mathrm{dy} ; 65- \\
80 \mathrm{y} ; 36 \\
917 / 25)\end{array}$ & $\begin{array}{l}\text { B. coagulans; } \\
1.0 \times 10^{9}\end{array}$ & $\begin{array}{l}\text { Significant increase in anti- } \\
\text { inflammatory cytokine IL-10. No } \\
\text { effect on NK or TNF- } \alpha\end{array}$ \\
\hline $\begin{array}{l}\text { Parra, et al. } \\
2004(54)\end{array}$ & $\begin{array}{l}\mathrm{RC}, \mathrm{DB} \\
\mathrm{P}\end{array}$ & $\begin{array}{l}\text { Probiotic } \\
\text { yoghurt/ } \\
\text { placebo }\end{array}$ & $\begin{array}{l}8 \mathrm{w} ; 51-58 \\
\mathrm{y} ; 23\end{array}$ & L. casei; $10^{8}-10^{10}$ & $\begin{array}{l}\text { Increased in NK cells activity and } \\
\text { oxidative burst capacity of } \\
\text { monocytes. No change in other } \\
\text { immune factors }\end{array}$ \\
\hline $\begin{array}{l}\text { Van } \\
\text { Puyenbroec } \\
\text { k, et al. } 2012 \\
\text { (48) }\end{array}$ & $\begin{array}{l}\mathrm{RC}, \mathrm{DB}, \\
\mathrm{P} ; \\
\text { Belgium }\end{array}$ & $\begin{array}{l}\text { Probiotic drink/ } \\
\text { placebo drink }\end{array}$ & $\begin{array}{l}176 \mathrm{dy} ; 55- \\
101 \mathrm{y} ; 737 \\
(184 / 553)\end{array}$ & $\begin{array}{l}\text { L. casei Shirota; } \\
1.3 \times 10^{10}\end{array}$ & $\begin{array}{l}\text { No significant effect on the } \\
\text { incidence or symptoms of flu }\end{array}$ \\
\hline $\begin{array}{l}\text { West, et al. } \\
2014(49)\end{array}$ & $\begin{array}{l}\mathrm{RC}, \mathrm{DB}, \\
\mathrm{P} ; \\
\text { Australia }\end{array}$ & $\begin{array}{l}\text { Probiotic } \\
\text { sachet/ placebo }\end{array}$ & $\begin{array}{l}150 \mathrm{dy} ; 18- \\
60 \mathrm{y} ; 465 \\
(241 / 224)\end{array}$ & $\begin{array}{l}\text { B. animalis subsp. } \\
\text { Lactis; } 2.0 \times 10^{9} \text { or } \\
\text { L. acidophilus and } \\
\text { B. animalis Lactis; } \\
5.0 \times 10^{9}\end{array}$ & $\begin{array}{l}\text { Significant reduction in the risk of } \\
\text { respiratory illness }\end{array}$ \\
\hline
\end{tabular}

CO: cross-over; DB: double blind; P: parallel; RC: randomized controlled trial; SA: single arm 
Table 3. Characteristics of included studies for the effect of probiotics on lipid profile and cardiovascular disease risk

\begin{tabular}{|c|c|c|c|c|c|}
\hline Study (year) & $\begin{array}{l}\text { Design; } \\
\text { Location }\end{array}$ & $\begin{array}{l}\text { Intervention/ } \\
\text { Control }\end{array}$ & $\begin{array}{l}\text { Duration; } \\
\text { Age; } \\
\text { participants } \\
(\mathbf{m} / \mathbf{f})\end{array}$ & $\begin{array}{l}\text { Probiotic; Dose } \\
\text { (per day), CFU }\end{array}$ & $\begin{array}{l}\text { Outcome effect; reported } \\
\text { side-effects }\end{array}$ \\
\hline $\begin{array}{l}\text { Agerbaek, } \\
\text { Gerdes and } \\
\text { Richelsen, } \\
1995(66)\end{array}$ & $\begin{array}{l}\mathrm{RC}, \mathrm{DB}, \\
\mathrm{P} ; \\
\text { Denmark }\end{array}$ & $\begin{array}{l}\text { Probiotic drink/ } \\
\text { placebo }\end{array}$ & $\begin{array}{l}6 \mathrm{wk} ; 44 \mathrm{y} \\
58(28 / 0)\end{array}$ & $\begin{array}{l}\text { E. faecium }+S . \\
\text { termophilus }\end{array}$ & $\begin{array}{l}\text { Significant reduction in } \mathrm{TC} \\
\text { and LDL-C }\end{array}$ \\
\hline $\begin{array}{l}\text { Bjerg, et al. } \\
2015(69)\end{array}$ & $\begin{array}{l}\mathrm{RC}, \mathrm{DB}, \\
\mathrm{P} ; \\
\text { Denmark }\end{array}$ & $\begin{array}{l}\text { Probiotic } \\
\text { capsule/ placebo }\end{array}$ & $\begin{array}{l}4 \mathrm{wk} ; 20- \\
54 \mathrm{y} ; 64 \\
(32 / 32)\end{array}$ & L. casei; $1.0 \times 10^{10}$ & Significant reduction in $\mathrm{TG}$ \\
\hline $\begin{array}{l}\text { Cox, et al. } \\
2014(62)\end{array}$ & $\begin{array}{l}\mathrm{RC}, \mathrm{DB}, \\
\mathrm{P} ; \\
\text { Australia }\end{array}$ & $\begin{array}{l}\text { Probiotic } \\
\text { sachet/ placebo }\end{array}$ & $\begin{array}{l}150 \mathrm{dy} ; 18- \\
60 \mathrm{y} ; 465 \\
(241 / 224)\end{array}$ & $\begin{array}{l}\text { B. animalis subsp. } \\
\text { Lactis; } 2.0 \times 10^{9} \text { or } \\
\text { L. acidophilus and } \\
\text { B. animalis Lactis; } \\
5.0 \times 10^{9}\end{array}$ & $\begin{array}{l}\text { No significant change. } \\
\text { Significant reduction in insulin } \\
\text { after double-strain } \\
\text { supplementation }\end{array}$ \\
\hline $\begin{array}{l}\text { de Roos, et } \\
\text { al. } 1999(18)\end{array}$ & $\begin{array}{l}\mathrm{RC}, \mathrm{DB}, \\
\mathrm{P} ; \\
\text { Netherlan } \\
\mathrm{ds}\end{array}$ & $\begin{array}{l}\text { Probiotic } \\
\text { yoghurt/ control } \\
\text { yoghurt }\end{array}$ & $\begin{array}{l}6 \mathrm{wk} ; 39.9 \pm \\
8.7 \mathrm{y} ; 78 \\
(22 / 56)\end{array}$ & $\begin{array}{l}\text { L. acidophilus; } \\
4.8 \times 10^{9}-2.7 \times 10^{10}\end{array}$ & $\begin{array}{l}\text { No significant changes in lipid } \\
\text { profile and BMI }\end{array}$ \\
\hline $\begin{array}{l}\text { Greany, et } \\
\text { al. } 2008(63)\end{array}$ & $\begin{array}{l}\text { RC, SB, P; } \\
\text { USA }\end{array}$ & $\begin{array}{l}\text { Probiotic } \\
\text { capsule/ placebo }\end{array}$ & $\begin{array}{l}8 \mathrm{wk} ; 18- \\
36 \mathrm{y} ; 55 \\
(22 / 33)\end{array}$ & $\begin{array}{l}\text { L. acidophilus and } \\
\text { B. longum } ; 1.0 \times 10^{9}\end{array}$ & No significant change \\
\hline $\begin{array}{l}\text { Higashikaw } \\
\text { a, et al. } 2010 \\
\text { (61)a }\end{array}$ & $\begin{array}{l}\mathrm{RC}, \mathrm{DB}, \\
\text { P: Japan }\end{array}$ & $\begin{array}{l}\text { Probiotic } \\
\text { yogurt/ placebo } \\
\text { yoghurt }\end{array}$ & $\begin{array}{l}6 \mathrm{wk} ; 37.3 \pm \\
12.2 \mathrm{y} ; 24 \\
(6 / 18)\end{array}$ & $\begin{array}{l}\text { L. plantarum } \\
S N 35 N ; 2 \times 10^{10}\end{array}$ & No significant Change \\
\hline $\begin{array}{l}\text { Higashikaw } \\
\text { a, et al. } 2010 \\
(61) b\end{array}$ & $\begin{array}{l}\mathrm{RC}, \mathrm{DB}, \\
\text { P: Japan }\end{array}$ & $\begin{array}{l}\text { Probiotic } \\
\text { yogurt/ placebo } \\
\text { yoghurt }\end{array}$ & $\begin{array}{l}6 \mathrm{wk} ; 35.1 \pm \\
11.6 \mathrm{y} ; 22 \\
(7 / 15)\end{array}$ & $\begin{array}{l}\text { L. plantarum } \\
S N 13 T ; 2 \times 10^{10}\end{array}$ & $\begin{array}{l}\text { Significant reduction in } \mathrm{TC} \\
\text { and LDL }\end{array}$ \\
\hline $\begin{array}{l}\text { Hulston, et } \\
\text { al. } 2015(71)\end{array}$ & $\begin{array}{l}\mathrm{RC}, \mathrm{P}, \\
\text { England }\end{array}$ & $\begin{array}{l}\text { Probiotic drink/ } \\
\text { placebo, + over } \\
\text { eating }\end{array}$ & $\begin{array}{l}4 \mathrm{wk} ; 24 \pm 2 \\
\mathrm{y} ; 8(7 / 1)\end{array}$ & $\begin{array}{l}\text { L.s casei Shirota; } \\
\text { (CFU not reported) }\end{array}$ & $\begin{array}{l}\text { Significant reduction in } \mathrm{TG} \text {, } \\
\text { No significant changes in BMI, } \\
\text { FBG or insulin level }\end{array}$ \\
\hline $\begin{array}{l}\text { Irwin et al. } \\
2017(65)\end{array}$ & $\begin{array}{l}\text { DB, R, P, } \\
\text { Australia }\end{array}$ & $\begin{array}{l}\text { Probiotic/ } \\
\text { placebo capsule }\end{array}$ & $\begin{array}{l}8 \text { wk } 27.9 \pm \\
6.5 ; 10(5 / 5)\end{array}$ & $\begin{array}{l}\text { L. acidophilus, } B \text {. } \\
\text { lactic; } 2.5 \times 10^{10}\end{array}$ & $\begin{array}{l}\text { No significant change. } \\
\text { Significant increase in BMI } \\
\text { and FBG }\end{array}$ \\
\hline $\begin{array}{l}\text { Klein, et al. } \\
2008(70)\end{array}$ & $\begin{array}{l}\mathrm{P}, \mathrm{RC} \\
\mathrm{CO} ; \\
\text { Germany }\end{array}$ & $\begin{array}{l}\text { Probiotic } \\
\text { yoghurt/ } \\
\text { placebo }\end{array}$ & $\begin{array}{l}5 \text { wk; } 25 \pm 3 \\
y ; 26(13 / 13)\end{array}$ & $\begin{array}{l}\text { L.acidophilus }+B \text {. } \\
\text { lactis } ; 9.4 \times 10^{8}\end{array}$ & Significant reduction in TG \\
\hline $\begin{array}{l}\text { Naruszewicz } \\
\text {, et al. } 2002 \\
(55)\end{array}$ & $\begin{array}{l}\mathrm{RC}, \mathrm{DB}, \\
\mathrm{P} \text {; Sweden }\end{array}$ & $\begin{array}{l}\text { Probiotic drink/ } \\
\text { placebo }\end{array}$ & $\begin{array}{l}6 \mathrm{wk} ; 35- \\
45 \mathrm{y} ; 36 \\
(18 / 18)\end{array}$ & $\begin{array}{l}\text { L. plantarum; } \\
2.0 \times 10^{10}\end{array}$ & $\begin{array}{l}\text { No significant change in lipid } \\
\text { profile, BMI, FBG or insulin } \\
\text { level }\end{array}$ \\
\hline
\end{tabular}




\begin{tabular}{|c|c|c|c|c|c|}
\hline $\begin{array}{l}\text { Osterberg, } \\
\text { et al. } 2015 \\
(72)\end{array}$ & $\begin{array}{l}\mathrm{RC}, \mathrm{DB} \\
\mathrm{P} ; \mathrm{USA}\end{array}$ & $\begin{array}{l}\text { Probiotic } \\
\text { capsule/ placebo } \\
+ \text { high fat diet }\end{array}$ & $\begin{array}{l}4 \mathrm{wk} ; 22.4 \pm \\
1.4 \mathrm{y} ; 9(9 / 0)\end{array}$ & $\begin{array}{l}\text { B. longum }+ \\
\text { B.infantis }+ \\
\text { B.breve }+ \text { L. } \\
\text { Acidophilus }+ \text { L. } \\
\text { paracasei }+\mathrm{L} . \\
\text { Bulgaricus }+ \text { L. } \\
\text { plantarum }+S . \\
\text { thermophiles; } 9.0 \\
\times 10^{11}\end{array}$ & $\begin{array}{l}\text { Lower increase in BMI after } \\
\text { high fat diet, no differences in } \\
\text { FBG }\end{array}$ \\
\hline $\begin{array}{l}\text { Rajkumar, } \\
\text { et al. } 2014 \\
(68)\end{array}$ & $\begin{array}{l}\mathrm{RC}, \mathrm{SB}, \mathrm{P}, \\
\text { India }\end{array}$ & $\begin{array}{l}\text { Probiotic } \\
\text { capsule/ placebo }\end{array}$ & $\begin{array}{l}6 \mathrm{wk} ; 40-60 \\
\mathrm{y} ; 15\end{array}$ & $\begin{array}{l}\text { B. longum }+ \\
\text { B.infantis }+ \\
\text { B.breve }+ \text { L. } \\
\text { Acidophilus }+ \text { L. } \\
\text { paracasei }+\mathrm{L} . \\
\text { Bulgaricus }+L . \\
\text { plantarum }+S . \\
\text { thermophilus }\end{array}$ & $\begin{array}{l}\text { Significant reduction in } \mathrm{TC} \\
\text { and } \mathrm{TG} \text {, increase in } \mathrm{HDL}-\mathrm{C} \text {, } \\
\text { and reduction in FBG and } \\
\text { insulin sensitivity }\end{array}$ \\
\hline $\begin{array}{l}\text { Rizkalla, et } \\
\text { al. } 2000(64)\end{array}$ & $\begin{array}{l}\mathrm{RC}, \mathrm{CO} \\
\text { France }\end{array}$ & $\begin{array}{l}\text { Yoghurt with } \\
\text { live culture/ } \\
\text { heated yoghurt }\end{array}$ & $\begin{array}{l}15 \mathrm{dy} ; 20- \\
60 \mathrm{y} ; 12 \\
(12 / 0)\end{array}$ & $\begin{array}{l}\text { L. bulgaricus }+S \text {. } \\
\text { thermophiles; } \geq \\
1.0 \times 10^{7}\end{array}$ & $\begin{array}{l}\text { No significant changes in lipid } \\
\text { profile, FBG or insulin levels }\end{array}$ \\
\hline $\begin{array}{l}\text { Sadrzadeh- } \\
\text { Yeganeh, et } \\
\text { al. } 2010(67)\end{array}$ & $\begin{array}{l}\mathrm{RC}, \mathrm{DB} \\
\mathrm{P} \text {; Iran }\end{array}$ & $\begin{array}{l}\text { Probiotic } \\
\text { yoghurt/ } \\
\text { Control }\end{array}$ & $\begin{array}{l}6 \mathrm{wk} ; 19- \\
49 \mathrm{y} ; 90 \\
(0 / 90)\end{array}$ & $\begin{array}{l}\text { B. lactis }+L \text {. } \\
\text { acidophilus; } \\
3.9 \times 10^{7}\end{array}$ & $\begin{array}{l}\text { Significant reduction in } \mathrm{TC} \\
\text { and increase in HDL-C, No } \\
\text { significant change in BMI }\end{array}$ \\
\hline
\end{tabular}

CO: cross-over; DB: double blind; FBG: fasting blood glucose; HDL-C: high-density lipoprotein cholesterol P: parallel; RC: randomized controlled trial; TC: total cholesterol; TG: triglyceride; 
Table 4. Characteristics of included studies for the effect of probiotics on gastrointestinal discomfort

\begin{tabular}{|c|c|c|c|c|c|}
\hline Study (year) & $\begin{array}{l}\text { Design; } \\
\text { Location }\end{array}$ & $\begin{array}{l}\text { Intervention/ } \\
\text { Control }\end{array}$ & $\begin{array}{l}\text { Duration; } \\
\text { Age; } \\
\text { participants } \\
(\mathbf{m} / \mathbf{f})\end{array}$ & $\begin{array}{l}\text { Probiotic; Dose } \\
\text { (per day), CFU }\end{array}$ & $\begin{array}{l}\text { Outcome effect; reported } \\
\text { side-effects }\end{array}$ \\
\hline $\begin{array}{l}\text { Del Piano, et } \\
\text { al. } 2010 \\
\text { (77)a }\end{array}$ & $\begin{array}{l}\mathrm{RC}, \mathrm{DB}, \\
\mathrm{P} \text {; Italy }\end{array}$ & $\begin{array}{l}\text { Probiotic blend/ } \\
\text { placebo }\end{array}$ & $\begin{array}{l}30 \mathrm{dy} ; 24- \\
71 \mathrm{y} ; 110 \\
(50 / 60)\end{array}$ & $\begin{array}{l}\text { L. plantarum }+B . \\
\text { breve; } 5 \times 10^{9}\end{array}$ & $\begin{array}{l}\text { Significant improvement in the } \\
\text { number of weekly bowel } \\
\text { movement and reduction in } \\
\text { abdominal irritation }\end{array}$ \\
\hline $\begin{array}{l}\text { Del Piano, et } \\
\text { al. } 2010 \\
\text { (77)b }\end{array}$ & $\begin{array}{l}\mathrm{RC}, \mathrm{DB} \\
\mathrm{P} \text {; Italy }\end{array}$ & $\begin{array}{l}\text { Probiotic blend/ } \\
\text { placebo }\end{array}$ & $\begin{array}{l}30 \mathrm{dy} ; 24- \\
71 \mathrm{y} ; 110 \\
(50 / 60)\end{array}$ & $\begin{array}{l}\text { B. animalis } \\
\text { subspecies lactis; } \\
5 \times 10^{9}\end{array}$ & $\begin{array}{l}\text { Significant improvement in the } \\
\text { number of weekly bowel } \\
\text { movement and reduction in } \\
\text { abdominal irritation }\end{array}$ \\
\hline $\begin{array}{l}\text { Higashikaw } \\
\text { a, et al. } 2010 \\
(61) a\end{array}$ & $\begin{array}{l}\mathrm{RC}, \mathrm{DB}, \\
\text { P: Japan }\end{array}$ & $\begin{array}{l}\text { Probiotic } \\
\text { yogurt/ placebo } \\
\text { yoghurt }\end{array}$ & $\begin{array}{l}6 \mathrm{wk} ; 35.1 \pm \\
11.6 \mathrm{y} ; 22 \\
(7 / 15)\end{array}$ & $\begin{array}{l}\text { L. plantarum } \\
S N 35 N ; 2 \times 10^{10}\end{array}$ & $\begin{array}{l}\text { Significant improvement in the } \\
\text { defection frequency }\end{array}$ \\
\hline $\begin{array}{l}\text { Higashikaw } \\
\text { a, et al. } 2010 \\
(61) b\end{array}$ & $\begin{array}{l}\mathrm{RC}, \mathrm{DB}, \\
\text { P: Japan }\end{array}$ & $\begin{array}{l}\text { Probiotic } \\
\text { yogurt/ placebo } \\
\text { yoghurt }\end{array}$ & $\begin{array}{l}6 \mathrm{wk} ; 35.1 \pm \\
11.6 \mathrm{y} ; 22 \\
(7 / 15)\end{array}$ & $\begin{array}{l}\text { L. plantarum } \\
\text { SN13T; } 2 \times 10^{10}\end{array}$ & $\begin{array}{l}\text { Significant improvement in the } \\
\text { defection frequency }\end{array}$ \\
\hline $\begin{array}{l}\text { Merenstein, } \\
\text { et al. } 2014 \\
(81)\end{array}$ & $\begin{array}{l}\mathrm{RC}, \mathrm{TB} \\
\mathrm{CO}, \mathrm{USA}\end{array}$ & $\begin{array}{l}\text { Probiotic } \\
\text { yoghurt/ } \\
\text { placebo }\end{array}$ & $\begin{array}{l}2 \mathrm{wk} ; 28.7 \pm \\
10.6 \mathrm{y} ; 68 \\
(0 / 68)\end{array}$ & $\begin{array}{l}\text { B. animalis ssp. } \\
\text { lactis } \mathrm{Bf}-6 ; 2 \times 10^{10}\end{array}$ & $\begin{array}{l}\text { No effect on the colonic transit } \\
\text { time, bowel movement or } \\
\text { frequency of constipation }\end{array}$ \\
\hline $\begin{array}{l}\text { Sakai, et al. } \\
2011 \text { (78) }\end{array}$ & $\begin{array}{l}\mathrm{RC}, \mathrm{P}, \\
\text { Belgium }\end{array}$ & $\begin{array}{l}\text { Fermented milk/ } \\
\text { placebo }\end{array}$ & $\begin{array}{l}3 \mathrm{w} ; 35.4 \pm \\
14.2 \mathrm{y} ; 19 \\
(11 / 8)\end{array}$ & $\begin{array}{l}\text { L. casei Shirota; } \\
6.5 \times 10^{9}\end{array}$ & $\begin{array}{l}\text { Significant reduction in the } \\
\text { incident of hard or lumpy stool }\end{array}$ \\
\hline
\end{tabular}

CO: cross-over; DB: double blind; P: parallel; RC: randomized controlled trial; $\mathrm{TB}$ : triple blind 
Table 5. Characteristics of included studies for the effect of probiotics on female reproductive health

\begin{tabular}{|c|c|c|c|c|c|}
\hline Study (year) & $\begin{array}{l}\text { Design; } \\
\text { Location }\end{array}$ & $\begin{array}{l}\text { Intervention/ } \\
\text { Control }\end{array}$ & $\begin{array}{l}\text { Duration; } \\
\text { Age; } \\
\text { participants } \\
(\mathbf{m} / \mathbf{f})\end{array}$ & $\begin{array}{l}\text { Probiotic; Dose } \\
\text { (per day), CFU }\end{array}$ & $\begin{array}{l}\text { Outcome effect; reported } \\
\text { side-effects }\end{array}$ \\
\hline $\begin{array}{l}\text { De Alberti, } \\
\text { et al. } 2015 \\
(86)\end{array}$ & $\begin{array}{l}\mathrm{RC}, \mathrm{DB}, \\
\mathrm{P} \text {; Italy }\end{array}$ & $\begin{array}{l}\text { Probiotic } \\
\text { capsule/ placebo }\end{array}$ & $\begin{array}{l}14 \mathrm{dy} ; 33.2 \\
\pm 9.7 \mathrm{y} ; 20\end{array}$ & $\begin{array}{l}\text { L. acidophilus }+L \text {. } \\
\text { rhamnosus } 1 \times 10^{10}\end{array}$ & $\begin{array}{l}\text { Significant increase in vaginal } \\
\text { concentration of specific } \\
\text { bacteria after intervention and } \\
\text { a week follow-up }\end{array}$ \\
\hline $\begin{array}{l}\text { Reid, et al. } \\
2003 \text { (87) }\end{array}$ & $\begin{array}{l}\mathrm{RC}, \mathrm{P} \\
\text { London }\end{array}$ & $\begin{array}{l}\text { Probiotic } \\
\text { capsule/ placebo }\end{array}$ & $\begin{array}{l}60 \mathrm{dy} ; 19- \\
46 \mathrm{y} ; 64\end{array}$ & $\begin{array}{l}\text { L. rhamnosus }+L . \\
\text { fermentum; } 10^{9}\end{array}$ & $\begin{array}{l}\text { Significant increase in vaginal } \\
\text { lactobacilli and reduce in yeast }\end{array}$ \\
\hline $\begin{array}{l}\text { Reid, et al. } \\
2001(85) a\end{array}$ & $\begin{array}{l}\mathrm{RC}, \mathrm{DB} \\
\text { Canada }\end{array}$ & $\begin{array}{l}\text { Probiotic } \\
\text { capsule }\end{array}$ & $\begin{array}{l}28 \mathrm{dy} ; 31 \pm \\
8 ; 33\end{array}$ & $\begin{array}{l}\text { L. rhamnosus }+L . \\
\text { fermentum; } 10^{8}- \\
10^{9}\end{array}$ & $\begin{array}{l}\text { Significant improvement in the } \\
\text { vaginal flora and health }\end{array}$ \\
\hline $\begin{array}{l}\text { Reid, et al. } \\
2001(85) b\end{array}$ & $\begin{array}{l}\mathrm{RC}, \mathrm{DB}, \\
\text { Canada }\end{array}$ & $\begin{array}{l}\text { Probiotic } \\
\text { capsule }\end{array}$ & $\begin{array}{l}28 \mathrm{dy} ; 31 \pm \\
8 ; 33\end{array}$ & L. rhamnosus GG & $\begin{array}{l}\text { No Significant change in } \\
\text { vaginal flora }\end{array}$ \\
\hline $\begin{array}{l}\text { Verdenelli, } \\
\text { et al. } 2016 \\
(82)\end{array}$ & SA, Italy & $\begin{array}{l}\text { Probiotic } \\
\text { suppositories }\end{array}$ & $\begin{array}{l}7 \mathrm{dy} ; 29.8 \pm \\
7.1 \mathrm{y} ; 35\end{array}$ & $\begin{array}{l}\text { L. rhamnosus }+L . \\
\text { paracasei; } 10^{9}\end{array}$ & $\begin{array}{l}\text { Significant increase in vaginal } \\
\text { lactobacilli }\end{array}$ \\
\hline
\end{tabular}

CO: cross-over; DB: double blind; P: parallel; RC: randomized controlled trial; SA: Single arm; TB: triple blind 


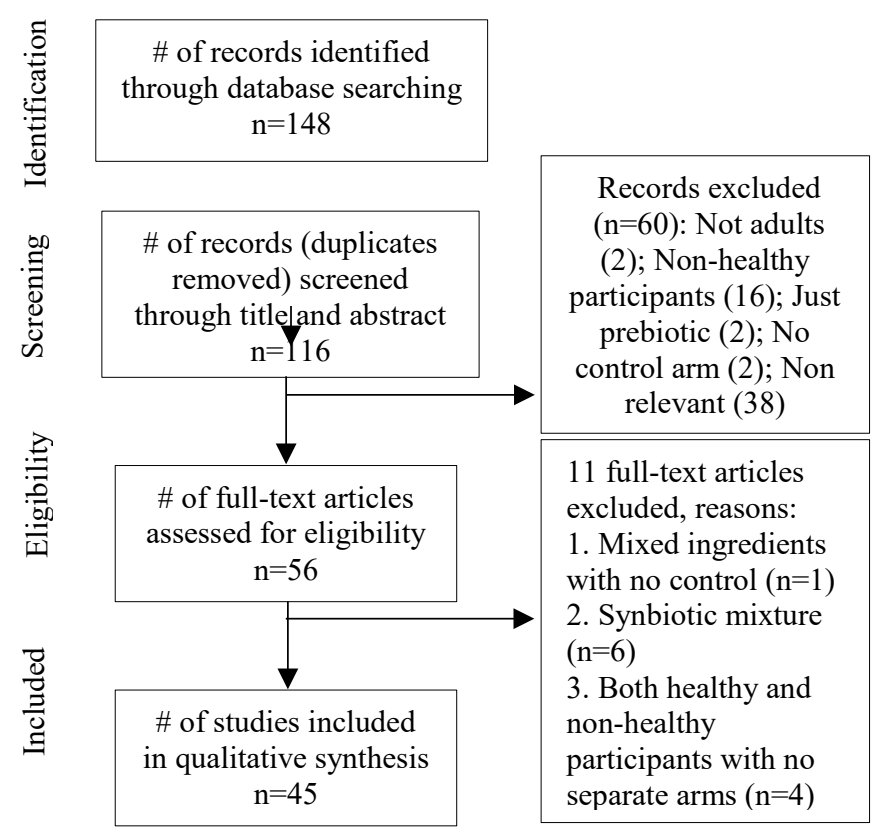

\section{Figure.1}

